\section{CALENDAR OF EVENTS}

\author{
Health Benefits and Dangers of \\ Exercise \\ 20 June 1996; Royal Society of Medicine \\ Further details: Alyson Taylor, Academic \\ Office, RSM, 1 Wimpole St, London W1. \\ $(\mathrm{Tel}+44$ (0) 171290 2985; fax +44 (0) 171 \\ 2989.)
}

Intermediate Sports Injury (course) 7-12 July 1996; Lilleshall Hall National Sports Centre, Shropshire (residential) Further details: Education Office, British Association of Sport and Medicine, c/o The National Sports Medicine Institute, Medical College of St Bartholomew's Hospital, Charterhouse Square, London EC1M 6BQ. (Tel +44 (0)171 253 3244; $\mathrm{fax}+44(0) 1712510774$.)

Overtraining and Overreaching in Sport: Physiological, Psychological and Biochemical Considerations

14-17 July 1996; University of Memphis, Memphis, Tennessee, USA

Further details: Laura Wilhelm, Human Kinetics, 1607 North Market Street, PO Box 5076, Champaign, IL 61825-5076, USA. (Tel +1 217351 5076; fax +1 217 351 2674.)

Introductory Sports Medicine (course) 22-27 September 1996; Lilleshall Hall National Sports Centre, Shropshire (residential)

Further details: Education Office, British Association of Sport and Medicine, c/o The National Sports Medicine Institute, Medical College of St Bartholomew's Hospital, Charterhouse Square, London EC1M 6BQ. (Tel +44 (0) 171253 3244; fax $+44(0) 1712510774$.)

Practical Sports Medicine (course) 3-10 October 1996; Club La Santa, Lanzarote (residential)

Further details: Education Office, British Association of Sport and Medicine, c/o The National Sports Medicine Institute, Medical College of St Bartholomew's Hospital, Charterhouse Square, London EC1M 6BQ. (Tel +44 (0) 171253 3244; fax $+44(0) 1712510774$.)

Fifteenth Congress of Sports Medicine of the AZ Sint-Jan

11-12 October 1996; Belfry Halls, Brugge, Belgium
Further details: J Gabriels, Revalidatiecentrum AZ St-Jan Ruddershove 10, B-8000 Brugge. (Tel +32(0)50 4522 30; fax. $+32(0) 50452917$.)

\section{BASM National Congress}

31 October - 3 November 1996; Slieve Donard Hotel, Newcastle, County Down, Northern Ireland

Further details: Education Office, British Association of Sport and Medicine, c/o The National Sports Medicine Institute, Medical College of St Bartholomew's Hospital, Charterhouse Square, London EC1M 6BQ. (Tel +44 (0)171 253 3244; fax +44 (0) 1712510774 .)

Intermediate Course: Sports Specific Injury Management and Normal Examination of Joints

17-22 November 1996; Lilleshall Hall National Sports Centre, Shropshire (residential)

Further details: Education Office, British Association of Sport and Medicine, c/o The National Sports Medicine Institute, Medical College of St Bartholomew's Hospital, Charterhouse Square, London EC1M 6BQ. (Tel +44 (0)171 253 3244; fax +44(0)1712510774.)

World Congress of Sports and Locomotor Medicines

27-29 December 1996; Colombo, Sri Lanka.

Sponsored by the Sri Lankan Government Ministry of Youth Affairs, Sports and Rural Development in association with Medicina Alternativa. Further details: Administrative Secretariat, 28 International Buddhist Centre Road, Colombo-6, Sri Lanka. (Tel +94-1-585242; fax +94-1-584148.)

Introductory Sports Medicine (course) 13-18 April 1997; Lilleshall Hall Nationa Sports Centre, Shropshire (residential) Further details: Education Office, British Association of Sport and Medicine, c/o The National Sports Medicine Institute, Medical College of St Bartholomew's Hospital, Charterhouse Square, London EC1M 6BQ. (Tel +44 (0) 171253 3244; fax $+44(0) 1712510774$.)

Intermediate Course: Sports Specific Injury Management and Normal Examination of Joints

13-18 July 1997; Lilleshall Hall National Sports Centre, Shropshire (residential)

Further details: Education Office, British Association of Sport and Medicine, c/o The National Sports Medicine Institute, Medical College of St Bartholomew's
Hospital, Charterhouse Square, London EC1M 6BQ. (Tel +44 (0)171 253 3244; fax $+44(0) 1712510774$.)

XIX Symposium of the European Group of Paediatric Work Physiology 16-21 September 1997. The Manor House Hotel, Moretonhampstead, Devon, UK.

Further details: Professor Neil Armstrong, Children's Health and Exercise Research Centre, University of Exeter, Heavitree Road, Exeter EX1 2LU. (Tel 01392 264812; fax 01392 264706.)

Introductory Sports Medicine (course) 21-26 September 1997; Lilleshall Hall National Sports Centre, Shropshire (residential)

Further details: Education Office, British Association of Sport and Medicine, c/o The National Sports Medicine Institute, Medical College of St Bartholomew's Hospital, Charterhouse Square, London EC1M 6BQ. (Tel +44 (0) 171253 3244; fax $+44(0) 1712510774$.)

Practical Sports Medicine (course) 2-9 October 1997; Club La Santa, Lanzarote (residential)

Further details: Education Office, British Association of Sport and Medicine, c/o The National Sports Medicine Institute, Medical College of St Bartholomew's Hospital, Charterhouse Square, London EC1M 6BQ. (Tel +44 (0) 171253 3244; fax +44 (0)171251 0774.)

\section{BASM Congress (London and South} East Region)

7-9 November 1997; Hotel Metropole, Brighton

Further details: Education Office, British Association of Sport and Medicine, c/o The National Sports Medicine Institute, Medical College of St Bartholomew's Hospital, Charterhouse Square, London EC1M 6BQ. (Tel +44 (0)171 2533244 ; fax $+44(0) 1712510774$. $)$

Intermediate Course: Sports Specific Injury Management and Normal Examination of Joints

23-29 November 1997; Lilleshall Hall National Sports Centre, Shropshire (residential)

Further details: Education Office, British Association of Sport and Medicine, c/o The National Sports Medicine Institute, Medical College of St Bartholomew's Hospital, Charterhouse Square, London EC1M 6BQ. (Tel +44 (0)171 2533244 ; fax $+44(0) 1712510774$.) 